\title{
Logarithmic quantitation model using serum ferritin to estimate iron overload in secondary haemochromatosis
}

\author{
T Güngör, E Rohrbach, E Solem, J P Kaltwasser, B Kornhuber
}

\begin{abstract}
Nineteen children and adolescents receiving repeated transfusions and subcutaneous desferrioxamine treatment were investigated in an attempt to quantitate iron overload non-invasively. Before patients were started on desferrioxamine individual relationships were correlated for 12 to 36 months between transfused iron, absorbed iron estimated gastrointestinally, and increasing serum ferritin concentrations. Patients with inflammation, increased liver enzymes, or haemolysis were excluded from analysis. The relationship between the variables could be described by a logarithmic regression curve ( $y=$ transfused iron [plus eventually gastrointestinally absorbed iron]=iron overload $=a+b \log [x=$ serum ferritin $]$ ) for each individual patient. All patients showed close correlation $\left(R^{2}\right)$ between $x$ and y (median $R^{2}$ of $0.909,0.98$, and 0.92 in thalassaemia, aplastic anaemia, and sickle cell anaemia patients, respectively). When started on desferrioxamine, current serum ferritin concentrations were used to derive the iron overload from each individual regression curve. The derived estimated iron overload ranged from $0.6 \mathrm{~g}$ to $31 \mathrm{~g}$. Left ventricular dilatation was observed in three patients with $\beta$ thalassaemia and in one patient with aplastic anaemia with median iron overload of $20.7(14 \cdot 1-31 \cdot 3) \mathrm{g}$ and $24.0 \mathrm{~g}$ respectively. Hypothyroidism was found in four patients with $\beta$ thalassaemia and one patient with aplastic anaemia with iron overload between $14 \cdot 7(6 \cdot 8$ and $26 \cdot 1) \mathrm{g}$ and $15 \cdot 1 \mathrm{~g}$ respectively. Human growth hormone deficiency was detected in three patients with $\beta$ thalassaemia with an iron overload of $4.2(3.5-6.8) \mathrm{g}$; all three patients had excellent desferrioxamine compliance.

(Arch Dis Child 1996; 74: 323-327)
\end{abstract}

Keywords: iron overload, ferritin, desferrioxamine, secondary haemochromatosis.

Secondary haemochromatosis with cardiomyopathy, liver cirrhosis, hypogonadism, delayed puberty, and diabetes are the most common complications of high transfusion regimens in children with $\beta$ thalassaemia, aplastic anaemia, and other refractory anaemias. ${ }^{1}$

After the introduction of chelation treatment with desferrioxamine, estimating iron overload became extremely important for therapeutic monitoring. One of the best and most reliable ways to estimate iron overload non-invasively is to determine the serum ferritin concentration, which correlates with rising parenchymal and non-parenchymal iron stores. ${ }^{2}$ One problem of this method is the wide range in the relationship between stored iron and ferritin (between 5 and $10 \mathrm{mg}$ iron/ng ferritin $/ \mathrm{ml}^{4}$ ). Other problems such as liver enzyme elevations, haemolysis, tumours, and inflammation may also influence this relationship.

In patients with severe haemochromatosis, other non-invasive techniques have been introduced such as SQUID (superconducting quantum interference device), dual energy computed tomography, and magnetic resonance imaging. ${ }^{5-7}$ All are expensive and time consuming and children require sedation or even anaesthesia. Other techniques, such as liver biopsy with measurement of liver iron content, are invasive with a risk of intraabdominal bleeding. ${ }^{89}$

The aim of this study was to improve the individual reliability of serum ferritin monitoring in patients with secondary iron overload using a simple logarithmic quantitation model that individualises the relationship of serum ferritin and iron stores.

\section{Subjects and methods}

Nineteen patients with refractory anaemia (14 with $\beta$ thalassaemia major, aged $3-18$ years; four with aplastic anaemia, aged 16-18 years; and one with sickle cell anaemia, aged 5 years) were investigated between 1975 and 1992 . All patients received regular leucocyte-poor red blood cell preparations every $2-4$ weeks to maintain haemoglobin concentrations $>100 \mathrm{~g} / \mathrm{l}$. Since 1979 , subcutaneous desferrioxamine (5-7 times/week, $30-100 \mathrm{mg} / \mathrm{kg}$ body weight) was given in those with imminent iron overload (ferritin concentrations $>1500$ $\mu \mathrm{g} / \mathrm{l})$. A transfusion requirement exceeding $240 \mathrm{ml} / \mathrm{kg} /$ year was considered an indication for splenectomy $(n=3)$. Measurements of urinary iron excretion (phenanthroline and tripyridiltriazine method) were regularly done to determine the most effective desferrioxamine dosage (faecal iron excretion was estimated to be $50 \%$ of total iron excretion). ${ }^{10}$ Amounts of transfused blood were noted and summated in each patient $(200 \mathrm{ml}$ leucocyte-poor blood $=200 \mathrm{mg}$ iron)

Serum ferritin concentrations were determined simultaneously and were excluded in 
patients with inflammation, increases in liver enzymes, or haemolysis.

As the majority of thalassaemic patients were on a high transfusion regimen (inhibiting erythropoeisis and excessive gastrointestinal iron absorption) from their first year of life their gastrointestinal iron absorption was estimated to be about $15 \%$ of food iron (table 1 ).

In those thalassaemic patients, who first received transfusions after infancy or had chronically low haemoglobin concentrations of $\leqslant 80 \mathrm{~g} / 1$ (no transfusions, after splenectomy) iron absorption was estimated to be about $30 \%$ of food iron (table 1). ${ }^{11}$

The correlation between serum ferritin concentrations and iron overload is described as a logarithmic regression curve or exponential curve. ${ }^{4}$ First, we determined the relationship between serum ferritin and iron overload in individual patients before desferrioxamine treatment was started. For this purpose each patient had serial serum ferritin measurements made during a period of 12-36 months. The level of iron stores was taken as 'transfused iron' ( $1 \mathrm{mg}$ iron $/ \mathrm{ml}$ blood transfused). For this period of time, gastrointestinal iron absorption was ignored in those patients who received their first blood transfusion in the first 12 months of life ( $y=$ transfused iron=iron over$\operatorname{load}=a+b \log [x=$ serum ferritin $])$. In others, who received their first blood transfusion after infancy, we estimated gastrointestinally absorbed iron and calculated iron stores as transfused iron plus absorbed iron ( $y=$ transfused iron $[+$ gastrointestinally resorbed iron $]=$ iron overload $=a+b \log [x=$ serum ferritin]). We plotted serum ferritin concentrations against iron load, producing regression curves for each patient (figs 1 and 2 ).

After desferrioxamine had been started, we measured serum ferritin concentrations and, using the regression curves previously determined for individual patients, derived a value for iron overload after desferrioxamine for each child. Next, we subtracted from this value the total amount of iron transfused and absorbed through the gastrointestinal tract to give a value for total faecal and urinary excretion of iron (table 2).

At the same time as measuring ferritin and iron overload, all patients had a regular (every 6-12 months) cardiovascular check up with echocardiography and/or radionuclide ventriculography. Endocrinological evaluation included thyrotrophin releasing hormone response and growth hormone values subse-

Table 1 Gastrointestinal absorption of iron based on an average iron content of food of $5.5 \mathrm{mg}$ iron/1000 kcal. Patients with $\beta$ thalassaemia with haemoglobin concentrations $>90$ gh have an average iron absorption of $15 \%$, patients with $\beta$ thalassaemia with haemoglobin concentrations $\leqslant 80$ g/ were estimated to have an iron absorption of $30 \%$. Modified according to Heinrich et al $^{11}$

\begin{tabular}{|c|c|c|c|c|c|}
\hline $\begin{array}{l}\text { Age } \\
\text { (years) }\end{array}$ & $\begin{array}{l}\text { Energy } \\
\text { intake } \\
\text { (kcal/day) }\end{array}$ & $\begin{array}{l}\text { Food iron } \\
\text { (mg/day) }\end{array}$ & $\begin{array}{l}\text { Physiological } \\
\text { loss of iron } \\
\text { (mg/day) }\end{array}$ & $\begin{array}{l}\text { Net iron intake } \\
\text { (mg/day) (15\% } \\
\text { intestinal absorption) }\end{array}$ & $\begin{array}{l}\text { Net iron intake } \\
\text { (mg/day) ( } 30 \% \\
\text { intestinal absorption) }\end{array}$ \\
\hline $\begin{array}{c}1-3 \\
4-6 \\
7-9 \\
10-12 \\
13-15 \\
16-18 \\
19-28\end{array}$ & $\begin{array}{l}1300 \\
1600 \\
2100 \\
2400 \\
3000 \\
3400 \\
2900\end{array}$ & $\begin{array}{c}7 \cdot 15 \\
8.8 \\
11.6 \\
13 \cdot 2 \\
16 \cdot 5 \\
18 \cdot 7 \\
16.0\end{array}$ & $\begin{array}{l}0.5 \\
0.5 \\
1.0 \\
1.0 \\
1.5 \\
1.5 \\
1.5\end{array}$ & $\begin{array}{l}0.5 \\
0.8 \\
0.75 \\
1.0 \\
1.0 \\
1.35 \\
0.95\end{array}$ & $\begin{array}{l}1 \cdot 5 \\
2 \cdot 1 \\
2 \cdot 5 \\
3 \cdot 0 \\
3 \cdot 5 \\
4 \cdot 15 \\
3 \cdot 3\end{array}$ \\
\hline
\end{tabular}

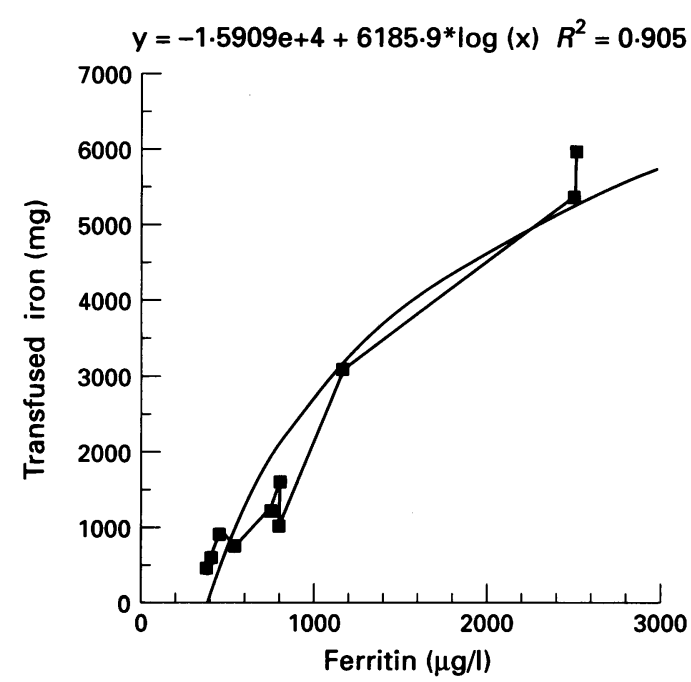

Figure 1 Patient 12 with $\beta$ thalassaemia had his first transfusion and ferritin determination within the first year of life. In this case the transfused iron was taken to be equivalent to 'iron overload' (the estimated gastrointestinally absorbed iron was ignored).

quent to arginine, clonidine, and growth hormone releasing factor. Haemoglobin, reticulocyte counts, and hepatitis A, B, HIV-1 and HIV-2 serology were done routinely before transfusion. In those with negative hepatitis B virus serology, hepatitis $\mathrm{B}$ vaccination was given.

\section{STATISTICAL ANALYSIS}

Median, mean, regression (logarithmic), $R^{2}$ values were obtained with Statview and Cricketgraph programs using a Macintosh Plus PC (Apple).

\section{Results}

In all patients, we found close correlation between individual ferritin determinations and the amount of transfused and gastrointestinally

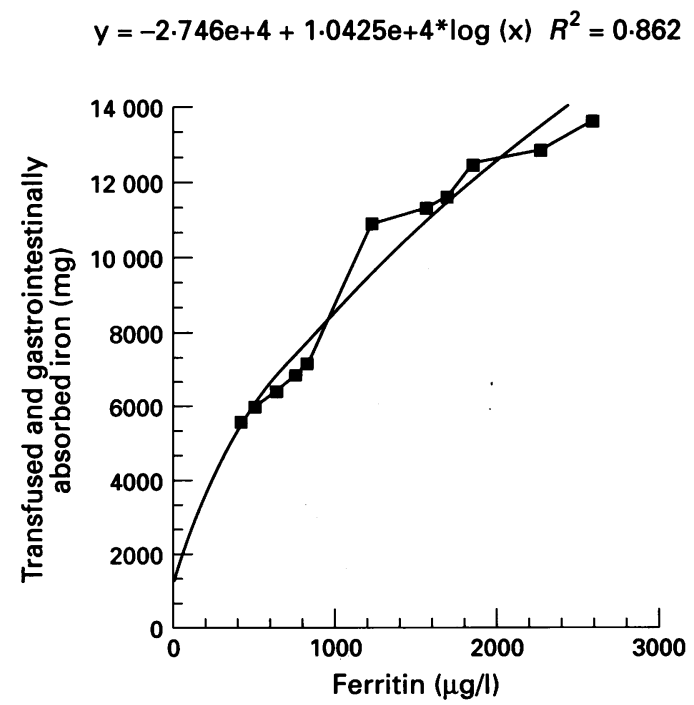

Figure 2 Patient 4 with $\beta$ thalassaemia had his first transfusion and ferritin determination at the age of 108 months. In this exceptional case with a long anaemic period, estimated gastrointestinally absorbed iron (about $6 \mathrm{~g}$ ) was added to the amount of transfused iron to give a measure of 'iron overload'. 
Table 2 Estimated gastrointestinally absorbed, excreted iron, and remaining iron overload

\begin{tabular}{|c|c|c|c|c|c|c|c|c|c|c|c|}
\hline $\begin{array}{l}\text { Patient } \\
\text { No }\end{array}$ & $\begin{array}{l}\text { Age } \\
\text { (years) }\end{array}$ & $\begin{array}{l}\text { Age at } \\
\text { first } \\
\text { transfusion } \\
\text { (months) }\end{array}$ & $\begin{array}{l}\text { Units of } \\
\text { blood } \\
\text { transfused }\end{array}$ & $\begin{array}{l}\text { Transfused } \\
\text { iron } \\
\text { (g) }\end{array}$ & $\begin{array}{l}\text { Gastrointestinally } \\
\text { absorbed } \\
\text { iron } \\
\text { (g) }\end{array}$ & $\begin{array}{l}\text { Total } \\
\text { iron } \\
\text { load } \\
(g)\end{array}$ & $\begin{array}{l}\text { Excreted iron } \\
\text { in urine and } \\
\text { faeces } \\
(\mathrm{g})\end{array}$ & $\begin{array}{l}\text { Iron } \\
\text { overload } \\
\text { (g) }\end{array}$ & $\begin{array}{c}\text { Actual } \\
\text { ferritin } \\
(\mu g / l)\end{array}$ & $\begin{array}{l}\text { Iron } \\
\text { overload } \\
\text { ferritin } \\
\text { ratio }\end{array}$ & $\mathbf{R}^{2}$ \\
\hline \multicolumn{12}{|c|}{$\beta$ Thalassaemia major } \\
\hline 1 & 18 & 12 & 382 & $80 \cdot 45$ & $5 \cdot 58$ & 86.03 & 59.93 & $26 \cdot 1$ & 5200 & 5.02 & 0.981 \\
\hline 2 & 18 & 122 & 337 & $69 \cdot 15$ & 7.97 & $77 \cdot 12$ & $45 \cdot 82$ & $31 \cdot 3$ & 5000 & $6 \cdot 26$ & 0.988 \\
\hline 3 & 16 & 31 & 198 & 39.58 & 5.87 & $45 \cdot 44$ & $31 \cdot 34$ & $14 \cdot 1$ & 4600 & 3.07 & 0.976 \\
\hline 4 & 17 & 108 & 191 & 39.95 & 7.05 & 47.00 & $31 \cdot 70$ & $15 \cdot 3$ & 4478 & $3 \cdot 42$ & 0.862 \\
\hline 5 & 11 & 19 & 176 & 34.80 & $2 \cdot 88$ & 37.68 & $27 \cdot 88$ & $9 \cdot 8$ & 1930 & 5.08 & 0.951 \\
\hline 6 & 10 & 6 & 159 & $31 \cdot 60$ & $1 \cdot 70$ & $33 \cdot 30$ & $26 \cdot 50$ & $6 \cdot 8$ & 4000 & 1.70 & 0.919 \\
\hline 7 & 14 & 36 & 133 & $27 \cdot 50$ & $4 \cdot 21$ & 31.71 & 17.61 & $14 \cdot 1$ & 4760 & 1.61 & 0.854 \\
\hline 8 & $7 \cdot 5$ & 6 & 103 & $19 \cdot 60$ & $2 \cdot 20$ & $21 \cdot 62$ & $18 \cdot 22$ & 3.4 & 1250 & $2 \cdot 72$ & 0.864 \\
\hline 9 & 8 & $7 \cdot 5$ & 97 & $19 \cdot 16$ & 2.02 & $21 \cdot 24$ & $17 \cdot 84$ & 3.5 & 1750 & $2 \cdot 00$ & 0.647 \\
\hline 10 & $7 \cdot 5$ & 24 & 92 & 18.70 & $2 \cdot 60$ & $21 \cdot 30$ & $11 \cdot 22$ & $10 \cdot 1$ & 2740 & 3.69 & 0.927 \\
\hline 11 & 6 & 3 & 84 & $15 \cdot 80$ & 1.38 & $17 \cdot 18$ & $14 \cdot 88$ & $2 \cdot 3$ & 700 & $3 \cdot 29$ & 0.893 \\
\hline 12 & 7 & 5 & 71 & 14.00 & 1.72 & $15 \cdot 72$ & 11.62 & $4 \cdot 1$ & 1700 & $2 \cdot 41$ & 0.905 \\
\hline 13 & 4 & 9 & 43 & $8 \cdot 40$ & 0.85 & $9 \cdot 25$ & $2 \cdot 25$ & 7.0 & 4300 & 1.63 & 0.903 \\
\hline 14 & 9 & 80 & 21 & $4 \cdot 15$ & 2.05 & $6 \cdot 20$ & 5.60 & 0.6 & 500 & $1 \cdot 20$ & 0.913 \\
\hline \multicolumn{12}{|c|}{ Aplastic anaemia } \\
\hline 15 & 18 & 133 & 203 & $43 \cdot 70$ & $6 \cdot 77$ & $50 \cdot 47$ & $26 \cdot 47$ & $24 \cdot 0$ & 4000 & $6 \cdot 00$ & 0.980 \\
\hline 16 & 18 & 126 & 201 & 38.05 & $2 \cdot 14$ & $40 \cdot 19$ & 23.49 & $16 \cdot 7$ & 3300 & 5.06 & 0.980 \\
\hline 17 & 18 & 126 & 155 & $30 \cdot 50$ & $3 \cdot 10$ & 33.60 & $26 \cdot 80$ & 6.8 & 1080 & $6 \cdot 30$ & 1.000 \\
\hline 18 & $17 \cdot 5$ & 98 & 140 & $30 \cdot 45$ & 3.86 & $34 \cdot 25$ & $19 \cdot 15$ & $15 \cdot 1$ & 1345 & $11 \cdot 23$ & 0.810 \\
\hline \multicolumn{12}{|c|}{ Sickle cell anaemia } \\
\hline 19 & $5 \cdot 5$ & 4 & 99 & $19 \cdot 90$ & $1 \cdot 74$ & $21 \cdot 63$ & $18 \cdot 31$ & $3 \cdot 3$ & 3000 & $1 \cdot 11$ & 0.925 \\
\hline
\end{tabular}

${ }^{\star} R^{2}$ values for logarithmic ferritin transfused iron regression curves.

absorbed iron. The curves shown in figs 3-5 represent the extrapolated 'idealised' logarithmic ferritin-iron overload regression curves of each individual patient, determined before desferrioxamine was started.

Using contemporaneously determined ferritin concentrations during desferrioxamine treatment, the individual iron overload could be derived from each individual regression curve. The median iron overload detected by this method was estimated as $8 \cdot 8(0 \cdot 6-31 \cdot 3) \mathrm{g}$ in $\beta$ thalassaemia, $15.9(6.8-24) \mathrm{g}$ in those with aplastic anaemia, and $3.25 \mathrm{~g}$ in the patient with sickle cell anaemia.

The median of estimated excreted iron was $18.05(2.25-59.93) \mathrm{g}$ in $\beta$ thalassaemia, 24.98 $(19 \cdot 15-26 \cdot 8) \mathrm{g}$ in those with aplastic anaemia, and $18.31 \mathrm{~g}$ in the patient with sickle cell anaemia (table 2).

Left ventricular dilatation proved by

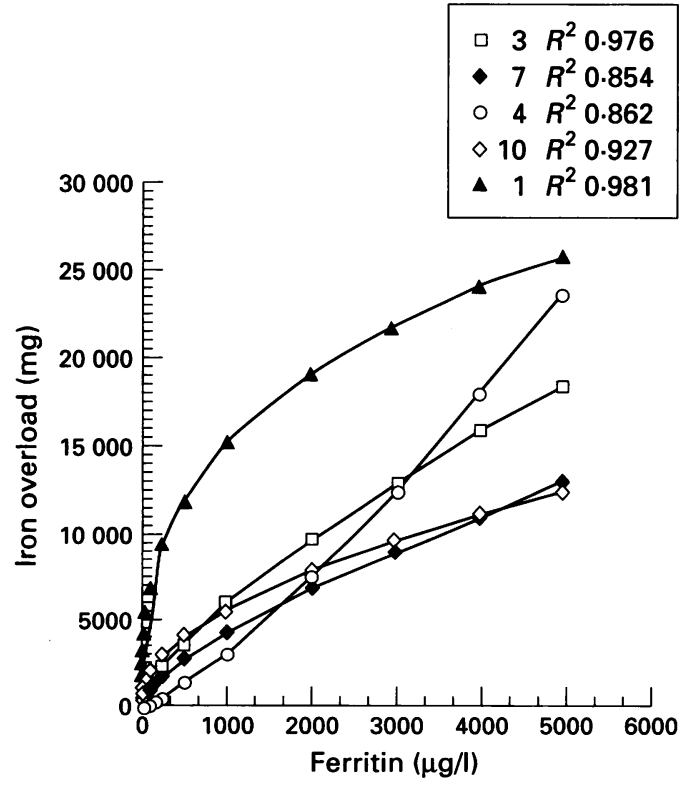

Figure 3 Course of extrapolated (idealised) logarithmic ferritin-iron overload regression curves in five patients with $\beta$ thalassaemia and moderate to severe secondary haemochromatosis. echocardiography was observed in three patients with $\beta$ thalassaemia with a median iron overload of $20 \cdot 7(14 \cdot 1-31 \cdot 3) \mathrm{g}$ and in one patient with aplastic anaemia with an iron overload of $24.0 \mathrm{~g}$. One patient in each group had a reduction in ejection fraction proven by radionuclide ventriculography (table 3 ).

Hypothyroidism was found in four patients with $\beta$ thalassaemia with a median iron overload of $14 \cdot 7(6 \cdot 8-26 \cdot 1) \mathrm{g}$ and in one patient with aplastic anaemia and an iron overload of $15 \cdot 1 \mathrm{~g}$ (table 3 ).

Human growth hormone deficiency was detected in three patients with $\beta$ thalassaemia with a median iron overload of $4 \cdot 2(3 \cdot 5-6 \cdot 8) \mathrm{g}$; all three patients had excellent desferrioxamine compliance (table 3 ).

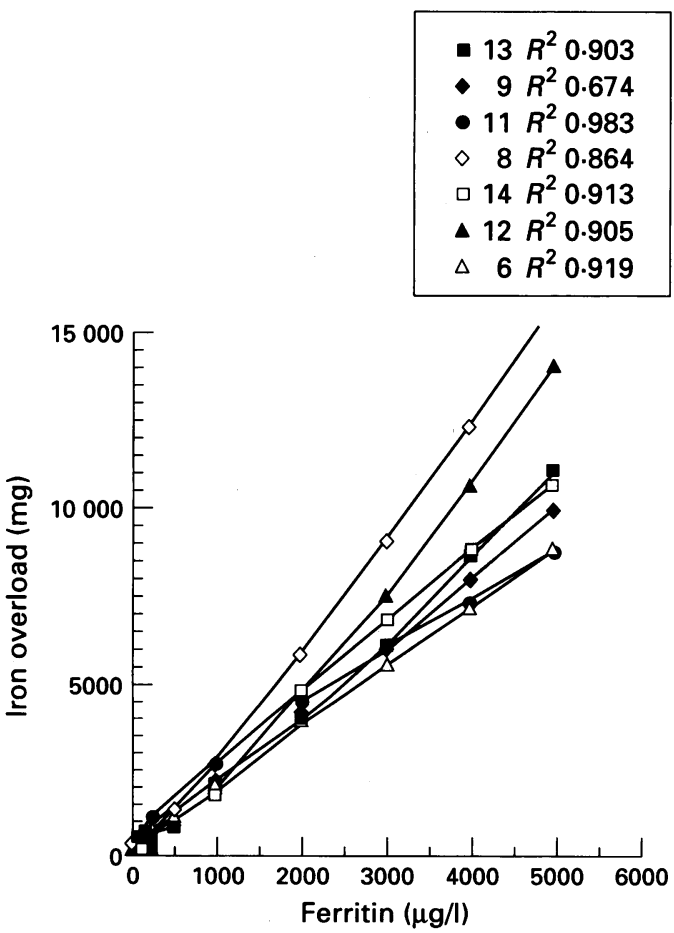

Figure 4 Course of extrapolated (idealised) logarithmic ferritin-iron overload regression curves in seven patients with $\beta$ thalassaemia and slight secondary haemochromatosis. 
- $16 R^{2} 0.98$

- $19 R^{2} 0.925$

- $15 R^{2} 0.98$

व $18 R^{2} 0.810$

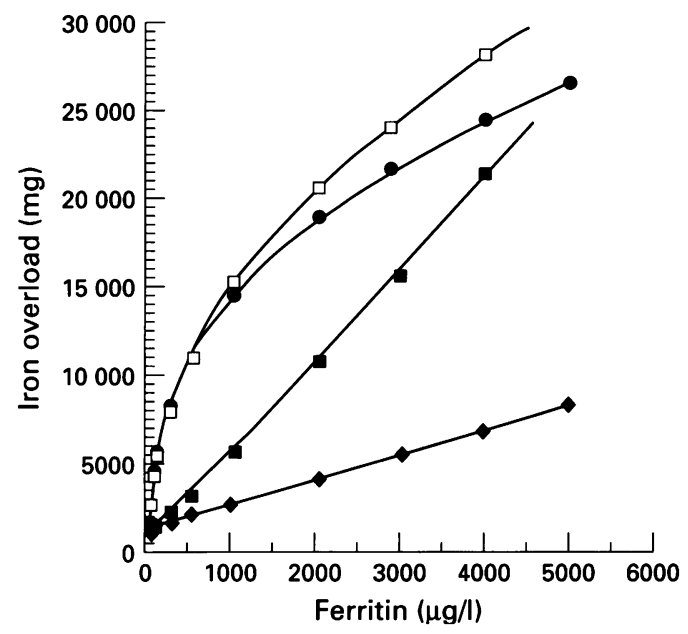

Figure 5 Course of extrapolated (idealised) logarithmic ferritin-iron overload regression curves in three patients with aplastic anaemia and one patient (19) with sickle cell anaemia.

\section{Discussion}

Non-invasive estimation of iron overload in secondary haemochromatosis is one of the main problems in monitoring desferrioxamine treatment. Although desferrioxamine is able to prevent and partially reverse tissue damage due to iron overload, ${ }^{12-15}$ to some degree, damage may be irreversible.

We have used a method to 'individualise' the relationship between iron overload and serum ferritin. The major part of iron load in chronic anaemia is the amount of transfused iron, which is easily calculated. Gastrointestinally absorbed iron can be a source of considerable iron loading in patients with $\beta$ thalassaemia ${ }^{1011}$ without regular transfusions. Consequently, in cases of $\beta$ thalassaemia with longer periods of anaemia

Table 3 Endocrine and cardiac involvement in patients with secondary haemochromatosis taking desferrioxamine

\begin{tabular}{|c|c|c|c|}
\hline $\begin{array}{l}\text { Patient } \\
\text { No }\end{array}$ & $\begin{array}{l}\text { Date of } \\
\text { splenectomy }\end{array}$ & $\begin{array}{l}\text { Cardiovascular status } \\
\text { (by } R N V^{\star} \text { and/or ultrasound) }\end{array}$ & Endocrine status $\dagger$ \\
\hline \multicolumn{4}{|c|}{$\beta$ Thalassaemia major } \\
\hline 1 & - & - & Hypothyroidism \\
\hline 2 & - & Left ventricular dilatation & - \\
\hline 3 & May 1977 & Left ventricular dilatation & Latent hypothyroidism \\
\hline 4 & - & Left ventricular dilatation & Latent hypothyroidism \\
\hline 5 & February 1979 & - & - \\
\hline 6 & - & - & $\begin{array}{l}\text { Hypothyroidism, decreased growth } \\
\text { hormone }\end{array}$ \\
\hline 7 & - & - & - \\
\hline 8 & - & - & - \\
\hline 9 & - & - & Decreased growth hormone \\
\hline 10 & - & - & - \\
\hline 11 & - & - & - \\
\hline 12 & - & - & Decreased growth hormone \\
\hline 13 & - & - & - \\
\hline 14 & - & - & - \\
\hline \multicolumn{4}{|c|}{ Aplastic anaemia } \\
\hline 15 & - & Left ventricular dilatation & - \\
\hline 16 & - & - & - \\
\hline 17 & - & - & - \\
\hline 18 & November 1977 & - & Hypothyroidism \\
\hline \multicolumn{4}{|c|}{ Sickle cell anaemia } \\
\hline 19 & - & - & - \\
\hline
\end{tabular}

$\star \mathrm{RNV}=$ Radionuclide ventriculography. †Assessed by thyrotrophin releasing hormone test, growth hormone after clonidine, arginine, and growth hormone releasing factor. $\leqslant 80 \mathrm{~g} / \mathrm{l}$ (for example, no transfusion due to splenectomy, $\beta$ thalassaemia intermedia, or caused by poverty) an estimate of gastrointestinally absorbed iron must be added to the amount of transfused iron before forming the ferritin-iron overload regression curve.

In patients with aplastic anaemia, sickle cell anaemia, and $\beta$ thalassaemia who are on high transfusion regimens, gastrointestinal iron absorption can be ignored in forming the ferritin-iron overload regression curve. ${ }^{10}$ When exclusion criteria for ferritin are considered, the relationship between transfused iron (plus gastrointestinally absorbed iron), liver iron content, and ferritin is close. ${ }^{3416}$

As myocardial siderosis is a significant contributing factor in the early death of patients with refractory anaemias ${ }^{13} 17$ we tried to confirm our iron studies by evaluating the cardiovascular status of our patients. According to our data, an iron overload of $\geqslant 14 \mathrm{~g}$ (ferritin about 4000-5000 $\mu \mathrm{g} / \mathrm{l}$ ) during desferrioxamine treatment can cause left ventricular dilatation due to cardiomyopathy (table 3 ).

Other investigations showed early cardiomyopathy after transfusion with 100 units of blood (about $20 \mathrm{~g}$ iron) in patients without desferrioxamine. ${ }^{18}$ This discrepancy might be explained by the fact that those patients with cardiomyopathy had received a total amount of iron greater than $30 \mathrm{~g}$ which might have damaged cardiac tissue before being partially removed by intensive desferrioxamine treatment. The same threshold of $14 \mathrm{~g}$ iron overload was also observed in hypothyroidism. All patients with hypothyroidism had an iron overload of $\geqslant 14 \mathrm{~g}$ except for one with an estimated iron overload of about $7 \mathrm{~g}$ (total received iron $33 \mathrm{~g}$, current serum ferritin $4000 \mu \mathrm{g} / \mathrm{l})$. This child had unexplained high ferritin concentrations even though the estimated iron overload was quite low and the desferrioxamine compliance was good. This patient will need a liver biopsy.

We discovered that all children with abnormal growth hormone values had a low iron burden and excellent desferrioxamine compliance (table 3). Whether neurotoxic adverse effects of desferrioxamine ${ }^{14} 15$ are responsible for this phenomenon is unclear and will require further investigation.

According to our experience, where liver enzymes are chronically raised or ferritin concentrations exceed $4000 \mu \mathrm{g} / \mathrm{l}$, desferrioxamine treatment has to be intensified to decrease ferritin and transaminases. For this purpose, high dose intravenous desferrioxamine via a Broviac catheter or Portsystems may be an alternative to subcutaneous desferrioxamine administration if compliance is poor. If it is possible to normalise transaminases and to reduce ferritin concentrations $\leqslant 4000 \mu \mathrm{g} / 1$ the logarithmic regression curve can be used to quantitate iron overload. If this is not possible, or rapid evaluation of iron status is necessary, magnetic resonance imaging (T2 relaxation time determination ${ }^{7}$ ), SQUID (if available), and/or liver biopsy and measurement of liver iron content is necessary. 
1 Finch CA. Hemochromatosis in hematology. 2nd Ed. New York: Mc-Graw Hill, 1972: 413-7.

2 Addison GM, Beamish MR, Hales $\dot{C}$, et al. An immunoradiometric assay for ferritin in the serum of norma subjects and patients with iron deficiency and iron overload. $f$ Clin Pathol 1972; 25: 326-9.

3 Cazzola M, Borgna-Pignatti C, Stefano PD, et al. Internal distribution of excess iron and sources of serum ferritin in patients with thalassaemia. Scandinavian fournal of Haematology 1983; 30: 289-96.

4 Kaltwasser JP, Werner E. Diagnosis and clinical evaluation of iron overload. Iron chelating therapy. Baillieres Clin Haematol 1989; 3: 363-89.

5 Brittenham GM, Farrell D, Harris JW, et al. Magnetic-susceptibility measurement of human iron stores. $N$ Engl $f$

6 Houang MTW, Arozena X, Skalicka A, et al. Correlation between computer tomographic values and liver iron content in thalassemia major with iron overload. Lancet 1979, i: $1322-3$.

7 Kaltwasser JP, Gottschalk R, Schalk KP, Hartl W. Noninvasive quantitation of liver iron overload by magnetic resonance imaging. $\mathrm{Br} \mathcal{F}$ Haematol 1990; 74: 360-3.

8 Barry M, Sherlock S. Measurement of liver-iron concentration in needle biopsy specimens. Lancet 1971; i: 100-3.

9 Bassett MI, Halliday JW, Powell LW. Value of hepatic iron measurements in early hemochromatosis and determination of the critical iron level associated with fibrosis. Hepatology 1986; 6: 24-9.

10 Pippard MJ. Iron overload and iron chelation therapy in thalassaemia and sickle cell haemoglobinopathies. Acta Haematol 1987; 78: 206-11.

11 Heinrich HC, Gabbe EE, Oppitz KH, et al. Absorption of inorganic and food iron in children heterozygous and homozycus $\beta$-thalassemia. Zeitschrift fur Kinderheilkunde 1973; 115: 1-22

12 Grisaru D, Goldfarb AW, Gotsman MS, et al. Deferoxamine improves left ventricular function in $\beta$-thalassemia. Arch Intern Med 1986; 146: 2345-9.

13 Wolfe L, Olivieri N, Sallan D, et al. Prevention of cardiac disease by subcutaneous deferoxamine in patients with disease by subcutaneous deferoxamine in patients

14 Olivieri NF, Buncic JR, Chew E, et al. Visual and auditory neurotoxicity in patients receiving subcutaneous deferroxamine infusions. $N$ Engl f Med 1986; 314: 869-73.

15 Schiliro G, Russo A. Reappraisal of high-dose desferrioxamine therapy. Acta Haematol 1986; 76: 63-4.

16 Prieto J, Barry M, Sherlock S. Serum ferritin in patients with iron overload and with acute and chronic live disease. Gastroenterology 1975; 68: 525-33.

17 Ehlers RH, Giardena PJ, Lesser ML, et al. Prolonged survival in patients with beta-thalassemia major treated with deferoxamine. F Pediatr 1990; 118: 540.

18 Buja LM, Roberts WC. Iron in the heart. Etiology and clinical significance. $A m \mathcal{F} M e d$ 1971; 51: 209-21. 